\title{
WIDESPREAD VIRAL DISEASES ENDANGERING CEREAL CROPS IN UKRAINE
}

\author{
H. Snihur, S. Petrenko, T. Kot, O. Shevchenko, V. Polischuk \\ Taras Shevchenko National University of Kyiv, \\ 64/13 Volodymyrska Str., Kyiv, 01601, Ukraine \\ e-mail: galya_snigur@yahoo.com
}

\begin{abstract}
Aim. Viral diseases are one of the factors governing yield of cereal crops which is a key element to guaranteeing food security in Ukraine. This work assesses spread of most harmful viruses infecting cereals in agriecosystems using different diagnostic approaches. Methods. Viruses were detected in collected samples using double-antibody sandwich enzyme-linked immunosorbent assay with commercial test systems specific to 12 cereal viruses. Transmission electron microscopy was used for direct detection of virus particles. Results. To evaluate the spread of cereal viruses, we have carried out a 15-year monitoring of cereal crops in different regions of Ukraine. For virus screening, we collected plants with typical virus-like symptoms (mosaic, leaf discoloration, etc.). We have identified arthropod-transmitted viruses: Barley yellow dwarf virus-PAV (BYDV-PAV), Barley yellow dwarf virus-MAV (BYDV-MAV), Cereal yellow dwarf virus-RPV (CYDV-RPV), Wheat streak mosaic virus (WSMV) and Wheat dwarf virus (WDV). Brome mosaic virus (BMV) and Barley stripe mosaic virus (BSMV) were sporadically detected in the commercial fields under cereals, as well as several soil-borne viruses, including Wheat spindle streak mosaic virus (WSSMV), Soil-borne cereal mosaic virus (SBCMV), Soil-borne wheat mosaic virus $(S B W M V)$ and Barley mild mosaic virus (BaMMV). Conclusions. Barley yellow dwarf virus-PAV, Wheat streak mosaic virus and Wheat dwarf virus are the most spread viruses endangering cereals' cultivation in Ukraine. During the last 15 years, these viruses gained not only in terms of spread but also in the context of their economic effect.
\end{abstract}

Keywords: cereal crops, Barley yellow dwarf virus-PAV, Barley yellow dwarf virus$M A V$, Cereal yellow dwarf virus-RPV, Wheat streak mosaic virus, Wheat dwarf virus, Brome mosaic virus, Barley stripe mosaic virus, Wheat spindle streak mosaic virus, Soilborne cereal mosaic virus, Soil-borne wheat mosaic virus, Barley mild mosaic virus.

Grain growing holds leading position in the agrarian industry of Ukraine. For many years, cereals remain important crops in every region of the country. Ukraine enjoys all prerequisites for growing high yields of cereals with gross grain yield reaching 60 million tons for most of the seasons. Winter wheat is a major cereal crop in Ukraine, as its cultivation is favored by typical soil/ climatic conditions in many of the regions. Winter wheat crops occupy 6-7 million ha totaling to $43 \%$ of area under cereals.

Cereal crops are unique in terms of their biological properties and accumulate large quantities of high-caloric organic compounds - proteins, carbohydrates, fats, macro- and microelements, and contain different enzymes (amylases, lipases, peroxidases, oxidases, etc.) as well as vitamins (B1, B2, B6, ascorbic acid, beta-carotene).

Due to the population upsurge and recognized importance of Poaceae plants for food security and availability, recent years witnessed increased attention to viral diseases of cereals. 
Economic significance of viral diseases of cereals is hard to overestimate as yield losses can reach $80-90 \%$ during epidemics. Virus infections affect and redirect physiological and biochemical processes in plants. Infected cereals demonstrate decreased stooling productivity (by 72-95\%), reduced content of chlorophyll and carotenoids, abnormal seed formation and impairment of seed quality (smaller number of seed in spikes, reduced seed weight (by 29-55\%), sharp decrease of gluten content) [1-14].

In Ukraine, viral diseases of cereals have been repeatedly described by many authors from 1960-ies. Biological properties of infectious agents, means of their transmission, spread, visual appearance of the disease on different crops as well as virulence were among the main subject of early studies [1-14]. As we know from literature, the following viruses were spread in various regions of Ukraine: Wheat streak mosaic virus (Tritimovirus, Potyviridae) [1-6], Barley yellow dwarf virus (Luteovirus, Luteoviridae) [7-10], Barley stripe mosaic virus (Hordeivirus, Virgaviridae) [3, 4], Brome mosaic virus (Bromovirus, Bromoviridae) $[4,10,11]$, as well as potentially harmful Barley yellow mosaic virus (Bymovirus, Potyviridae) transmitted via fungi-like organisms Polymyxa graminis $[12,13]$. Moreover, there were several outdated communications regarding the possible occurrence of Winter wheat (Russian) mosaic virus (Cytorhabdovirus, Rhabdoviridae) and Wheat dwarf virus (Mastrevirus, Geminiviridae) transmitted by a leafhopper Psammotettix alienus [10, 11, 14] requiring additional confirmation.

Modern approaches to studying ecological and epidemiological features of viral diseases of cereal crops envisage the accumulation of experimental data on spread and strain diversity of viruses, as well as on their vectors, host range and reservoirs. When coupled with data on spectrum of cultivated crops, climatic conditions and geographical peculiarities, this information is a necessary prerequisite for designing a system for risk assessment of plant virus epidemics for given regions.

In view of aforesaid, this work was focused on the complex monitoring of the most harmful viruses endangering cereal crops in agriecosystems of Ukraine.

Materials and methods. To evaluate the occurrence and spread of cereal viruses, we have carried out a 15 -year monitoring of cereal crops in agriecosystems of different parts of Ukraine including Vinnytsya, Dnipropetrivsk, Kyiv, Lviv, Mykolayiv, Odessa, Poltava, Kharkiv, Kherson, Khmelnytskiy, Cherkassy and Chernihiv regions. When surveying the crops, we collected plants with typical virus-like symptoms and also noted the approximate percentage of diseased plants using an approach adopted by Spaar, occurrence of insect vectors as well as concomitant bacterial and fungi diseases [15]. Virus detection in collected samples was done using doubleantibody sandwich enzyme-linked immunosorbent assay (DAS-ELISA) with commercial test systems purchased from Loewe and DSMZ (Germany), and Agdia (USA) specific to the following viruses: Wheat streak mosaic virus (WSMV), Barley stripe mosaic virus (BSMV), Brome mosaic virus (BMV), Wheat dwarf virus (WDV), Barley yellow dwarf virus-PAV (BYDV-PAV), Barley yellow dwarf virus-MAV (BYDV-MAV), Cereal yellow dwarf virus- 
RPV (CYDV-RPV), Barley yellow mosaic virus (BaYMV), Barley mild mosaic virus (BaMMV), Wheat spindle streak mosaic virus (WSSMV), Soil-borne cereal mosaic virus (SBCMV), and Soil-borne wheat mosaic virus (SBWCM). The analysis was performed following the manufacturer's recommendations. Absorbance values, measured 60 min after adding the substrate, greater than two times those of the negative controls and exceeding 0,2 were considered positive [16]. Transmission electron microscopy was used for direct detection of virus particles in cereal samples. To remove the debris, plant samples were homogenized in 0,1M PBS (pH 7,4) and centrifuged at $4000 \mathrm{rpm}$ for $15 \mathrm{~min}$. The supernatant was deposited on $0.2 \%$ formvare membranes and contrasted for 10 min using $2 \%$ uranyl acetate [17].

Results. For 15 years, we have been conducting the monitoring of spiked grains for viral infections in different parts of Ukraine. For virus screening, we collected plants with typical virus-like symptoms including streak and stripe mosaic, yellowing and reddening of leaf blades, stunting and dwarfing. Varied and diverse virus-specific symptoms were noted on different crops in different regions. Yellowing of leaves of winter wheat was common for the central part of Ukraine (Fig.1a), when reddening of leaves was more typical for southern regions (Fig.1b).

a)

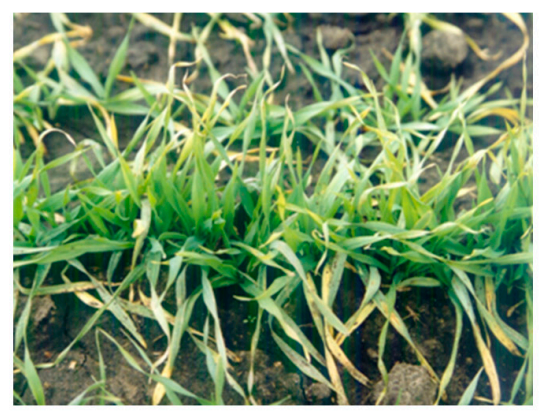

b)

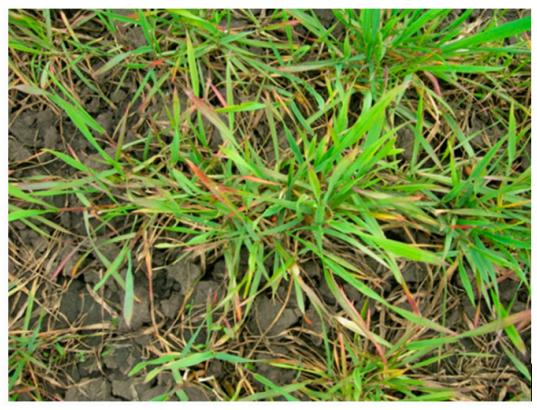

Fig. 1 - Symptoms of viral disease on winter wheat plants from Vinnytsya (a) and Odessa (b) regions

We also noted various mosaic symptoms - from minor streak mosaic (Fig.2a) to stripe light green mosaic (Fig.2b), - sometimes even on the same field.

a)

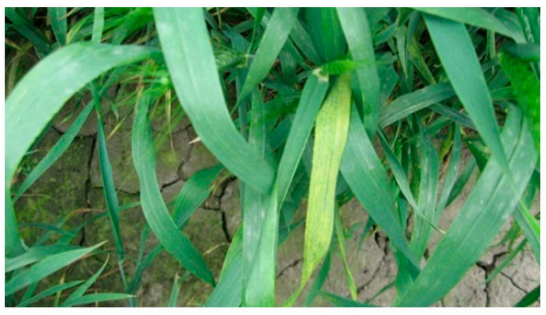

b)

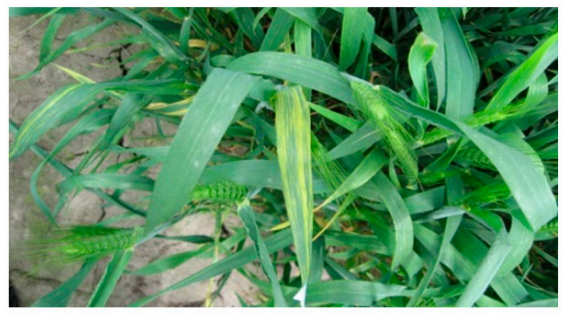

Fig. 2 - Symptoms of mosaic on leaves of winter wheat from Kyiv region:

a) minor streak mosaic; b) light green stripe mosaic 
Serological screening of collected samples showed presence of viruses which were known to be widespread pathogens in Ukraine such as WSMV, BSMV, BMV, WDV, and also viruses belonging to barley yellow dwarf group. These, in particular, included Barley yellow dwarf virus-PAV (BYDV-PAV), Barley yellow dwarf virus-MAV (BYDV-MAV), and Cereal yellow dwarf virus-RPV (CYDV-RPV) - formerly recognized as strains of BYDV but now declared as distinct virus species from different genera of Luteoviridae family [18]. In addition, the samples have been also checked serologically for cereal soil-borne viruses transmitted by fungi-like organisms Polymyxa graminis which endanger European countries nowadays. In Europe, seven soil-borne viruses are widespread and 5 of them (Barley yellow mosaic virus (BaYMV), Barley mild mosaic virus (BaMMV), Wheat spindle streak mosaic virus (WSSMV), Soil-borne cereal mosaic virus (SBCMV), and Soil-borne wheat mosaic virus (SBWCM) pose a major threat for commercial cultivation of winter varieties of wheat, rye, triticale, and barley [19-22]. Taking this into account, we analyzed plant samples collected in agriecosystems from different regions of Ukraine for these 5 pathogens.

In line with obtained results, Barley yellow dwarf virus-PAV, Wheat streak mosaic virus, and Wheat dwarf virus are the most spread viruses prevailing in Ukrainian agriecosystems. These viruses are efficiently transmitted by arthropods - respectively, by aphids, mites and leafhoppers.

Barley yellow dwarf virus- $P A V$ was repeatedly found in plants of winter and spring wheat, winter and spring barley, winter rye, spring oat, triticale and wild cereal grasses collected nearby commercial plantings. Infected plants demonstrated symptoms of yellowing and reddening of leaf blades followed by stunting. Sometimes the visual symptoms persisted from autumn time, in spring they typically developed in April. Our data confirm regular annual spread of BYDV-PAV on cereals in different parts of Ukraine including Vinnytsya, Kyiv, Lviv, Mykolayiv, Odessa, Kharkiv, Kherson, Khmelnytskiy, Cherkassy and Chernihiv regions (totaling to nearly half of the country). In years 2005, 2006 and 2009, BYDV-PAV was confirmed as a casual agent of epiphytoties in the western (Lviv, Khmelnytskiy), southern (Odessa, Mykolayiv), and central regions (Vinnytsya, Cherkassy).

Apart from BYDV-PAV, Barley yellow dwarf virus-MAV has been detected on winter wheat plants only, and Cereal yellow dwarf virus-RPV - on winter wheat and winter barley plants from Odessa region. Typically, higher percentage of infected plants and larger affected areas were characteristic for southern regions. This is obviously connected with optimal climatic conditions favouring spread of aphids which serve as virus vectors.

Aphids Sitobion avena, Rhopalosiphum padi, and Schizaphis graminum (known vectors for many viruses) were found during plant screening for virus diseases in different regions of Ukraine. In the context of cereal viruses it is on interest that Sitobion avena transmits two viruses (BYDV-PAV and BYDVMAV), when Rhopalosiphum padi is able to vector BYDV-PAV, CYDV-RPV, and CYDV-RPS. From there pathogens, only CYDV-RPS was never found. In addition, Schizaphis graminum was also reported as a tentative vector for BYDV-PAV [23]. The occurrence of three aphid species capable of transmitting Barley yellow dwarf virus-PAV may explain the abundance and relative dominance of this virus in Ukrainian agriecosystems. 
Spread of diseases and related yield losses greatly depend on complex relations among plant hosts, viruses and their vectors, as well as on climatic conditions which govern vectors' activity and reproduction. This complicates both forecasting of the occurrence of viral diseases and decision making for direct vector control. Despite the availability of marketed insecticides for seed treatment and field protection, such approach may not be commercially viable each year. Viruses of barley yellow dwarf group are transmitted persistently and hence require a prolonged period of vector feeding on phloem sap (typically about several hours are needed for successful virus transmission). This factor determines rather high efficiency of chemical insecticidal substances used for plant protection. Vectors normally die before transmitting the virus (or at least enough of virus to induce the disease). The time of treatment, however, is a crucial step for successful vector control. Basing on experimental data, it is thought that insecticides are not efficient in preventing the initial crop infection by coming vectors (typically their population only contains approximately $4 \%$ of viruliferous insects) but demonstrate high potential for limiting further spread of the virus in crops [24, 25].

Wheat streak mosaic virus is transmitted by mite Aceria tritici and was found in winter and spring varieties of wheat and barley in Vinnytsya, Dnipropetrivsk, Kyiv, Odessa, Poltava, Kharkiv, Cherkassy, and Chernihiv regions. Diseased plants developed different patterns of streak and stripe mosaic (Fig.2). Regardless of the varying types of mosaic, the ELISA results confirmed that all such plants were infected by the same Wheat streak mosaic virus, as other pathogens were not detected. Evidently, varying types of WSMV symptoms were due to differences in winter wheat varieties. This pathogen was most frequently found in northern and eastern parts of the country back in 2007, 2008 and in the autumn of 2012. In addition to vector transmission, WSMV was also shown to be transmitted by seed $(0,5-1,5 \%)$ for both wheat and maize [26]. When coupled with vector transmission, this rather low efficiency of seed transmission enables WSMV to induce epiphytoties and facilitates virus spread into new areas. In $21^{\text {st }}$ century, WSMV was found in South Europe [27, 28], Australia, etc. [29]. In Germany, another related virus has been isolated from meadow grass (Poa pratensis) genbank and characterized in detail [30]. This striking evidence underpins the need to re-evaluate our views on WSMV epidemiology and its spread with sowing material as well as material from the genbanks.

Wheat dwarf virus was identified in different cultivars of winter and spring wheat, and winter barley collected from Kyiv, Mykolayiv, Odessa, Kharkiv, Khmelnytskiy, and Cherkassy regions. Surprisingly, for the first time WDV has been also detected in samples of durum and concomitant wild cereal grasses of Deschampsia genus. Infected plants developed yellowing, severe dwarfing, and poor or no spikes. WDV is transmitted persistently by a leafhopper Psammotettix alienus which occur in Ukraine. Favoring climatic conditions and non-compliance with approved agritechniques may be the factors facilitating epiphytoty of WDV. Differential PCR-based diagnostics of serologically WDVpositive samples showed that the vast majority of plants collected from various regions of Ukraine were infected by wheat strain of WDV. However, a single sample of winter wheat (cultivar Selyanka) collected from Odessa region was infected by barley strain of WDV providing novel data on virus biology [31]. 
Cereal yield losses invoked by arthropod-transmitted viruses depend on (i) productivity of diseased plants, (ii) compensatory capabilities of healthy neighbor plants, and (iii) virus accumulation in reservoir plants (both cultivated and wild-growing) enabling preservation of virus population during winter. These factors are keys to maintaining infection chain. Elimination of infection sources is not practical as these viruses have far too many host plants (wild cereals). For instance, viruses of barley yellow dwarf group enjoy as much as 150 species of host plants belonging to 5 subfamilies of Poaceae family. From such plants the viruses are then transmitted to commercial crops by arthropods. It is often unreal to maintain proper distance between wheat or barley plantings and meadows, pastures and maize plantings. Complex approach of virus control is aimed at breaking the infection chain. In this context, the priority task is to eliminate seeds' fall during stubble processing. Usually, the seeds' fall plantings are heavily infected by viruses and serve as optimal sources of inocula for transmission of viruses by vectors to winter cereal crops. Also, the more dense the plantings, the more aphids and leafhoppers they attract. In addition, early sowing of winter crops coincides with high percentage of viruliferous vectors. When coupled with warm weather favoring vector spread and feeding, early sowing in autumn has higher risks of virus spread before winter, and the yield losses can lead up to $70 \%$. Spring cereals are typically less susceptible to virus damage because of the late flight of viruliferous vectors. Virus infections endanger successful overwintering of winter cereal crops. Moreover, virus-infected plants are an easy ground for secondary fungi diseases including Pseudocercosporella herpotrichoides, Fusarium sp., etc. leading to even higher yield losses [25, 32].

In addition to aforementioned viruses, Brome mosaic virus (BMV) and Barley stripe mosaic virus (BSMV) were sporadically detected in the commercial fields under cereals. Brome mosaic virus was most often found in winter wheat and spring barley plants collected from Kyiv and Vinnytsya regions back in 2003, as well as in winter wheat and barley from Odessa region in 2008. This virus induces severe losses of grain yield reaching 35$65 \%$. Early infection of winter and spring barley, wheat or oat may lead to total loss of crops. In turn, Barley stripe mosaic virus was found in winter wheat only collected from Kyiv and Poltava regions in 2003, Vinnytsya region in 2006, Vinnytsya and Kharkiv regions in 2007, and Kyiv region in 2008. This pathogen is especially harmful because of extremely high efficiency of its seed transmission (up to $90 \%$ ) and transmission by pollen. This means that up to $90 \%$ of plants germinated from virus-contaminated seeds will be infected. Sometimes, however, the disease is symptomless which pose a great danger for selection. The efficiency of BSMV seed transmission depends on virus strain, term of plant infection, and on plant species/cultivar.

Figure 3 represents summary data on virus monitoring and prevalence in cereal crops by region.

We used electron microscopy for direct detection of most common cereal viruses. We have found spherical particles of two types differing in their diameter: about $18 \mathrm{~nm}$ (typical for Wheat dwarf virus, Fig.4a) and $27 \mathrm{~nm}$ (Brome mosaic virus, Fig.4b). Also, when studying sap of infected plants, filamentous virus particles $(700 \times 11-15 \mathrm{~nm})$ typical for Wheat streak mosaic virus were detected (Fig.4c), as well as rod-shaped virions (120-150 x $20 \mathrm{~nm})$ 


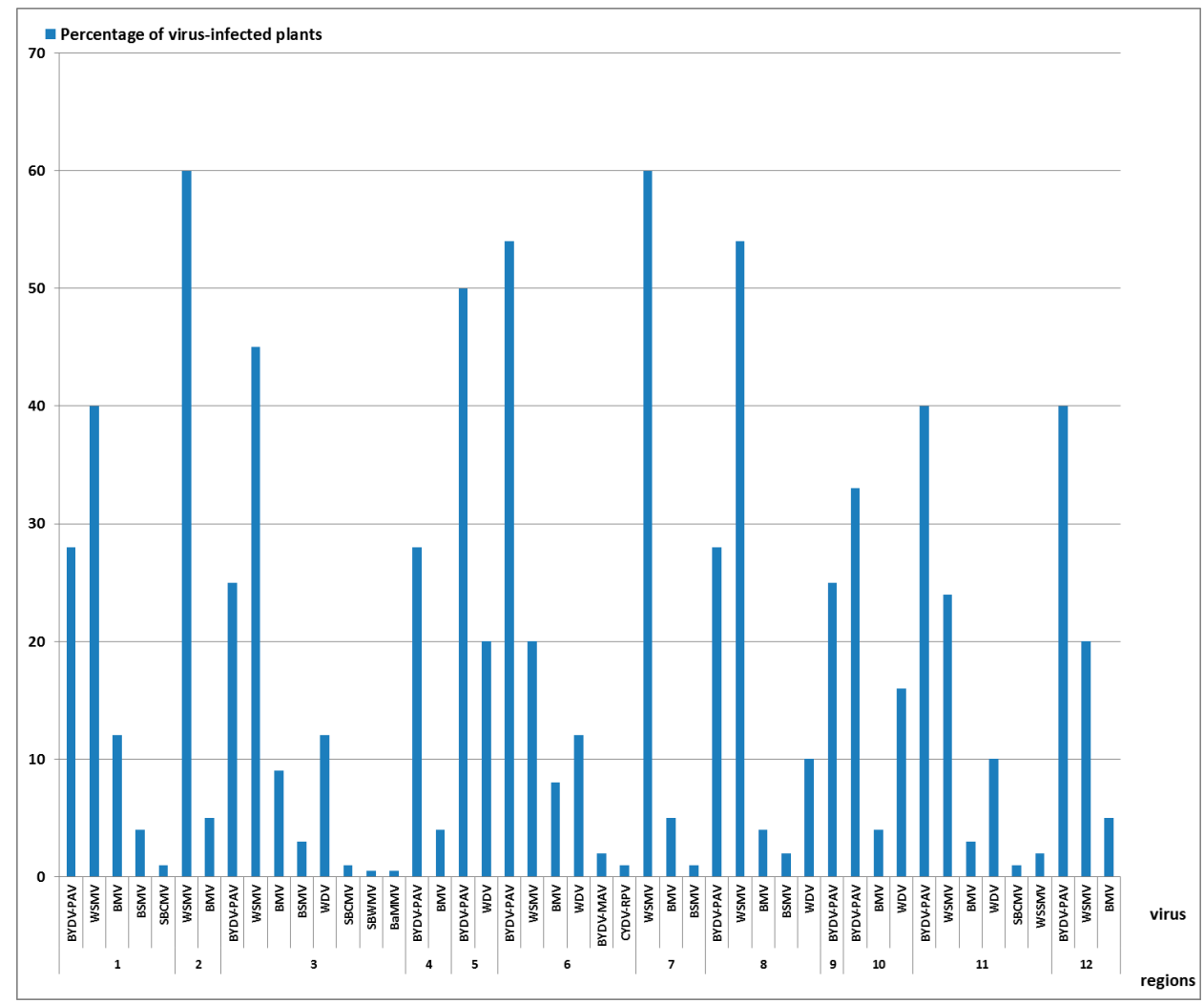

Fig.3 - Detection of cereal viruses in grain cereals by region (2002-2016): 1 - Vinnytsya, 2 - Dnipropetrivsk, 3 - Kyiv, 4 - Lviv, 5 - Mykolayiv, 6 - Odessa, 7 - Poltava, 8 - Kharkiv, 9 - Kherson, 10 - Khmelnytskiy, 11 - Cherkassy, 12 - Chernihiv

characteristic for Barley stripe mosaic virus (Fig.4d). These data were in agreement with the results of ELISA of the same samples using specific test systems toward respective viruses.

a)

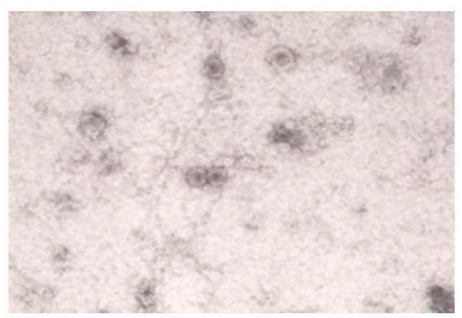

c)

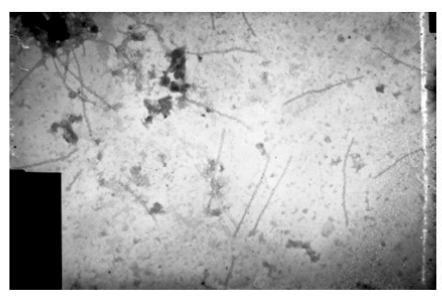

b)

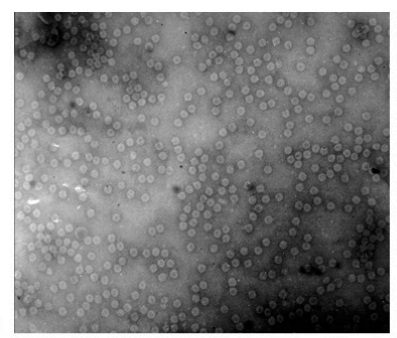

d)

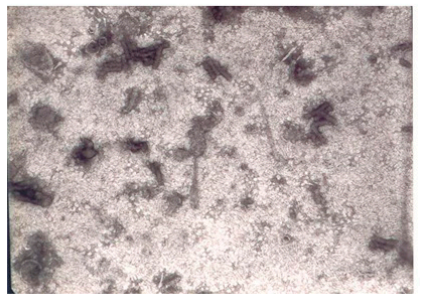

Fig. 4 - Electron microscopy images of Wheat dwarf virus (a), Brome mosaic virus (b), Wheat streak mosaic virus (c) and Barley stripe mosaic virus (d) 
Taking into account the danger imposed by Polymyxa graminis-transmitted viruses for cultivation of wheat, rye, barley and triticale in Europe [19-22], we surveyed Ukrainian agriecosystems for the presence of 5 most harmful soil-borne viruses typical for European countries. The obtained results showed the occurrence of WSSMV, SBWMV, SBCMV, and BaMMV, and confirmed the presence of spores of vector Polymyxa graminis in the root system of infected plants. SBCMV was the most common pathogen found, in particular, in winter rye (cultivar Arfa) collected from Cherkassy region in 2004, and in winter wheat and wild grasses collected immediately after wheat sowing from Vinnytsya region in 2005. In wild grasses, SBCMV was found in association with BMV and BYDV-PAV.

The epidemiology of soil-borne viruses is such that spores of fungi vector serve as the main reservoir for virus. These spores can survive in soil for up to 20 years, thus successfully preserving the virus in infectious state. This means that crop rotation or suspension of cultivation of susceptible crops have no positive effect. Spores of Polymyxa graminis are extremely stable to low temperatures and can easily overwinter. Also, they are insusceptible to high temperatures as the fungi can reach deep into the ground. Hence, thermal treatment of fungi vector is both inefficient and ecologically unsafe. Viruscontaminated spores are easily spread by agricultural machinery on the field and with soil particles to the surrounding areas (and even to the distant regions with wind). All soil-borne viruses favor lower temperatures: they accumulate to higher titers, develop more pronounced symptoms, and induce higher losses of plants during overwintering. This is why winter cultivars tend to be more susceptible to soil-borne viruses when spring varieties may evade the infection [33-36].

Discussion. Intensification of cereals' cultivation, active importing of seed material and global warming (i.e., vector spread to new areas) are major factors favoring the spread of cereal viruses. More accurate virus diagnostics using modern serological and molecular techniques also adds to our knowledge. However, sometimes virus symptoms can be easily confused with those induced by non-infectious factors, i.e. draught, excess moisture, low temperature, nutrient deficiency, etc. The development of state-of-the-art experimental methods will facilitate differential diagnostics.

In summary of the obtained results we should note that Barley yellow dwarf virus-PAV, Wheat streak mosaic virus and Wheat dwarf virus are the most ubiquitous virus pathogens endangering cereals' cultivation in Ukraine. During the last 15 years, these viruses gained not only in terms of spread but also in the context of their possible economic effect.

In the view of epidemiological characteristics of these cereal viruses (highly susceptible hosts, efficient (or only) vector transmission, and wide spread in the country), it is vital to ensure proper control of Barley yellow dwarf virusPAV, Wheat streak mosaic virus and Wheat dwarf virus in Ukraine via applying adequate phytosanitary measures to prevent spread of pathogens and vectors. Obtained results will from a base for developing prognostic system for virus control in Ukraine. 


\title{
ПОШИРЕНІ ВІРУСНІ ХВОРОБИ, ЩО ЗАГРОЖУЮТЬ ВИРОЩУВАННЮ ЗЕРНОВИХ КУЛЬТУР В УКРАЇНІ
}

\author{
Снігур Г.О., Петренко С.М., Кот Т.Г., Шевченко О.В.,Поліщук В.П.
}

Київський національний університет імені Тараса Шевченка, вул. Володимирська, 64, Київ, 01033, Украӥна

\section{Резюме}

Мета. Вірусні хвороби є одним з визначальних факторів якісних та кількісних показників урожаю зернових культур - ключового елементу забезпечення продовольчої безпеки в Україні. Метою роботи була оцінка поширення найбільш небезпечних вірусів злакових культур в агроекосистемах, використовуючи різні методи діагностики. Методи. Для ідентифікації вірусів у відібраних зразках використовували імуноферментний аналіз в модифікації DAS-ELISA із застосуванням комерційних тест-систем до 12 вірусів злакових. Для прямого виявлення вірусних часток застосовували метод трансмісівної електронної мікроскопії. Результати. Протягом 15 років проводились обстеження зернових колосових культур на предмет вірусних інфекцій у різних областях України. Для діагностики вірусів відбирали рослини з характерними симптомами (мозаїкою, зміною кольору листків та ін.). В результаті проведеної роботи в агроценозах України виявили віруси, що передаються членистоногими: Barley yellow dwarf virus-PAV, Barley yellow dwarf virus-MAV, Cereal yellow dwarf virus-RPV, Wheat streak mosaic virus та Wheat dwarf virus. Періодично ідентифікували Brome mosaic virus, Barley stripe mosaic virus та деякі грунтові віруси, зокрема, Wheat spindle streak mosaic virus, Soil-borne cereal mosaic virus, Soil-borne wheat mosaic virus i Barley mild mosaic virus. Висновки. Основну небезпеку для вирощування зернових культур в Україні складають Barley yellow dwarf virus-PAV, Wheat streak mosaic virus та Wheat dwarf virus. За останні 15 років в Україні в значній мірі збільшилась кількість і розповсюдженість вірусів, що уражують зернові культури.

Ключові слова: зернові культури, Barley yellow dwarf virus-PAV, Barley yellow dwarf virus-MAV, Cereal yellow dwarf virus-RPV, Wheat streak mosaic virus, Wheat dwarf virus, Brome mosaic virus, Barley stripe mosaic virus, Wheat spindle streak mosaic virus, Soil-borne cereal mosaic virus, Soil-borne wheat mosaic virus, Barley mild mosaic virus.

\section{РАСПРОСТРАНЕННЫЕ ВИРУСНЫЕ ЗАБОЛЕВАНИЯ, УГРОЖАЮЩИЕ ВЫРАЩИВАНИЮ ЗЕРНОВЫХ КУЛЬТУР В УКРАИНЕ}

\author{
Снигур Г.А., Петренко С.М., Кот Т.Г., Шевченко А.В., Полищук В.П. \\ Киевский национальный университет имени Тараса Шевченко, \\ ул. Владимирская, 64/13, Киев, 01033, Украина
}

\section{Резюме}

Цель. Вирусные заболевания являются одним из определяющих факторов урожая зерновых культур - ключевого элемента продовольственной безопасности Украины. Целью работы была оценка распространения наиболее вредоносных вирусов злаковых культур в агроэкосистемах с использованием разных методов диагностики. Методы. Для идентификации вирусов использовали иммуноферментный анализ в 
модификации DAS-ELISA с применением коммерческих тест-систем к 12 вирусам злаковых. Для прямого обнаружения вирусных частиц применяли метод трансмиссионной электронной микроскопии. Результаты. В течение 15 лет проводились обследования зерновых колосовых культур на предмет вирусных инфекций в разных областях Украины. Для диагностики вирусов отбирали растения с характерными симптомами (мозаикой, изменением цвета листьев и т.п.). В результате проведенной работы в агроценозах Украины обнаружили вирусы, передаваемые членистоногими: Barley yellow dwarf virus-PAV, Barley yellow dwarf virus-MAV, Cereal yellow dwarf virus-RPV, Wheat streak mosaic virus и Wheat dwarf virus. Периодически идентифицировали Brome mosaic virus, Barley stripe mosaic virus и некоторые почвенные вирусы, в частности, Wheat spindle streak mosaic virus, Soil-borne cereal mosaic virus, Soil-borne wheat mosaic virus и Barley mild mosaic virus. Выводы. Основную опасность для выращивания зерновых культур в Украине представляют Barley yellow dwarf virus-PAV, Wheat streak mosaic virus и Wheat dwarf virus. За последние 15 лет в Украине в значительной степени увеличилось количество и распространенность вирусов, поражающих зерновые культуры.

Ключевые слова: зерновые культуры, Barley yellow dwarf virus-PAV, Barley yellow dwarf virus-MAV, Cereal yellow dwarf virus-RPV, Wheat streak mosaic virus, Wheat dwarf virus, Brome mosaic virus, Barley stripe mosaic virus, Wheat spindle streak mosaic virus, Soil-borne cereal mosaic virus, Soil-borne wheat mosaic virus, Barley mild mosaic virus.

1. Razvyazkina HM, Belyanchykova YuV. Virus polosatoy mozaiki pshenicy, ego svojstva i rasprostranenie v prirode. In: Virusnye bolezni i mery borby s nimi. Kiev; 2002: 313318. Russian.

2. Olejnyk AN. Polosataya mosaika pshenicy na Ukraine. Avtoref. dis. kand. boil. nauk, K., 1968. 15s. Russian.

3. Shevchenko GP. Virusnye bolezni zernovyh zlakov v pravoberegnoj lesostepi Ukrainy: Avtoref. dis. kand. boil. nauk. MSKh SSSR. K., 1971. 28s. Russian.

4. Shevchenko GP, Helman L.V., Nedbyga O.E. ta in. Virusni ta mikoplazmovi khvoroby poljovyh kultur. K.: Urogaj, 1995. 304s. Ukrainian.

5. Mischenko LT, Bojko AL. Virus smugastoi mozaiky pshenyci v Ukraini. Dopovidi Nacionalnoi akademii nauk Ukrainy. 2004; 2: 176-180. Ukrainian.

6. Mischenko LT. Virusni khvoroby ozymoi pshenyci. K.: Fitosociocentr, 2009. 352s. Ukrainian.

7. Heshele EE, Dutko VP. Virus geltoj karlikovosti yachmena. Selskoye hozyajstvo za rubegom. 1972; 6: 56-58. Russian.

8. Nikolenko MP. Massovye razmnogenia zlakovyh tlej v svyazi s ih virusnoj vektornostyu. Uspehi entomologii SSSR. Ekologia i faunistika, nebolshie otryady nasekomyh. 1993: 144-145. Russian.

9. Yukhymenko AI, Hirko AI, Polischuk VP, Bojko AL. Govta karlykovist yachmenu. Epiphitotia virusu v sezoni 1998-1999 rokiv. Zahust Roslyn. 2000; 3: 6-7. Ukrainian.

10. Mogaeva KA. Virusnye bolezni zlakov v Rossii i Ukraine. M.: RASkhN, CNSKhB, Vseros. NII fitopatologii, 2003. 36s. Russian.

11. Moskovec SM, Bobyr AD, Hlushak LYe, Onyschenko AM. Virusni khvoroby silskogospodarskyh kultur. K.: Urogai, 1975. 152s. Ukrainian. 
12. Fantakhun AT, Pavlenko LA, Bobyr AD. Bozbuditel geltoj mosaiki yachmenya na Ukraine. Microbiol. gurnal. 1987; 49(3): 76-78. Russian.

13. Omelchenko LI, Simonenko VK, Bondarenko IR. Virus geltoj mosaiki yachmena na yuhe Ukrainy. Microbiol. gurnal. 1996; 58(2): 58-61. Russian.

14. Aharkov VA. Mosaika ozimoj pshenicy na Pravoberege USSR. Virusnye bolezni selskohozyajstvennyh kultur na Ukraine. K.: USKhA, 1959: 39-50. Russian.

15. Zaschita rastenij v ustojchivyh sistemah zemlepolzovania (v 4-h knigah). Pod obschej redakciej doktora s.-h. nauk, professora, inostrannogo chlena RASHN D. Spaar. 2004. Kniga 4. 345 s. Russian.

16. ELISA: theory and practice / edited by John R. Crowther. p. cm. (Methods in molecular biology, v. 42) 1995; 223 p.

17. Mironov AA, Komissarchik YaYu, Mironov VA. Metody elektronnoj mikroskopii v biologii i medicine. S-P.: Nauka, 1994, 399 p. Russian.

18. Virus Taxonomy. Ninth Report of the International Committee on Taxonomy of Viruses. - Academic Press, 2012. 1327 p.

19. Proeseler G, Stanarius A. Nachweis des Weizenspindelstrichelmosaik-Virus (wheat spindle streak mosaic virus) in der DDR. Arch. Phytopathol. Pflanzensch. 1983; 19: 345-349. German.

20. Proeseler G, Stanarius A, Szigat G, Herold H. Verbreitung von Barley mild mosaic virus (BaMMV) und Barley yellow mosaic virus (BaYMV) in der ehemaligen DDR sowie Gegenmassnahmen. Nachrichtenbl. Deut. Pflanzenschutzd. 1991; 43: 65-68. German.

21. Koenig R, Huth W. Natural infection of wheat by the type strain of Soil-borne wheat mosaic virus in a field in southern Germany. Europ. J. Pathol. 2003; 109: 191-193.

22. Kastirr U, Rabenstein F, Kuhne T. Soil-borne cereal mosaic - Soil-borne cereal mosaic furovirus. In: Lapierre, H. \& Signoret, P.-A. (Eds.) Viruses and Virus Diseases of Poaceae (Gramineae). INRA Editions Paris. 2004: 580-585.

23. Gray SM, Caillaud MC, Burrows M, Smith DM. Transmission of two viruses that cause Barley Yellow Dwarf is controlled by different loci in the aphid, Schizaphis graminum. Journal of Insect Science. 2007; 7(25): 1-15.

24. McKirdy SI, Jones RA. Use of Imidacloprid and newer generation synthetic pyretroids to control the spread of barley yellow dwarf luteovirus in cereals. Pl. Disease. 1996; 80: 895-901.

25. Spaar D, Rabenstein F, Kastirr U, Khaberus A. Viral diseases in the severe threat to the growing of grain crops in Europe. Vesci naciyanalnaj akademii navuk Belarusi. Seria agrarnyh navuk. 2006; 3: 60-70.

26. Jones RAC, Coulls BA, Маскіe AE, Dwyer GI. Seed transmission of Wheat streak mosaic virus shown unequivocally in wheat. Plant Dis. 2005; 89: 1048-1050.

27. Bakardjieva N, Krasteva C, Habekuss A, Rabenstein F. Detection of cereal viruses and study of aphid population in Bulgaria. Bulgarian J. Agricultural Science. 2004; 10 : 161-164.

28. Rabenstein F, Seifers DL, Schubert J et al. Phylogenetic relationships, strain diversity and biogeography of tritimoviruses. J. Gen. Virol. 2002; 83: 895-906.

29. Dwyer GI, Gibbs MJ, Gibbs AJ, Jones RAC. Wheat streak mosaic virus in Australia: Relationship to isolates from the Pacific Northwest of the USA and its dispersion via seed transmission. Plant Dis. 2007; 91: 164-170. 
30. Rabenstein F, French R, Stenger DC. Oat necrotic mottle tritimovirus. In: Lapierre, H. \& Signoret, P.-A. (Eds.) Viruses and Virus Diseases of Poaceae (Gramineae). INRA Editions Paris. 2004: 492-494.

31. Tobias I, Shevchenko O, Kiss B, Bysov A, Snihur H, Polischuk V, Salanki K, Palkovics L. Comparison of the Nucleotide Sequences of Wheat Dwarf Virus (WDV) isolates from Hungary and Ukraine. Polish Journal of Microbiology. 2011; 60(2): 125131.

32. Huth W. Barley yellow dwarf - ein permanentes Problem in der Bundesrepublik Deutschland Nachrichtenbl. Deut. Pflanzenschutzd. 1990; 42: 33-39. German.

33. Proeseler G, Kastirr U. Untersuchungen zur Wirkung von Fungiziden gegen Polymyxa graminis Led. Als Vektor des Gerstengelbmosaik-Virus. Nachrichtenbl. Pflanzenschutz. DDR. 1988; 42: 116-117. German.

34. Huth W, Lesemann DE. Fungus-transmitted soil-borne viruses on rye in Germany. J. Plant Disease and Protection. 1996; 103: 120-124.

35. Huth W. Im Getreidebau in Deutschland und in Europa wird eines der großten phytopathologischen Probleme erwartet: die bodenburtigen Viren des Weizens und Roggens. Nachrichtenbl. Deut. Pflanzenschutzd. 2000; 52: 196-198. German.

36. Kastirr U, Rabenstein F, Kühne T. Epidemiological aspects of soil-borne viruses of wheat, triticale and rye in Germany. Proc. 6th Symp. Int. Working Group Plant Viruses with Fungal Vectors. - Bologna, Italien. 2006: 132-136.

Отримано 01.09.2017 